九州大学学術情報リポジトリ

Kyushu University Institutional Repository

\title{
Application of Plant Growth Regulators on the Parthenocarpic Fruit Development in Teasle Gourd (Kakrol, Momordica dioica Roxb.)
}

Rasul, Mohammad Golam

Departmetn of Genetics and Plant Breeding, Bangabandhu Sheikh Mujibur Rahman Agricultural University

Mian, Mohammad Abdul Khaleque

Departmetn of Genetics and Plant Breeding, Bangabandhu Sheikh Mujibur Rahman Agricultural University

Cho, Yasuhiro

Departmetn of Plant Resources, Graduate School of Bioresource and bioenvironmental Sciences, Kyushu University

Ozaki, Yukio

Department of Plant Resources, Faculty of Agriculture, Kyushu University

他

https://doi.org/10.5109/10067

出版情報 : 九州大学大学院農学研究院紀要. 53 (1), pp.39-42, 2008-02-28. Faculty of Agriculture， Kyushu University

バージョン :

権利関係 : 


\title{
Application of Plant Growth Regulators on the Parthenocarpic Fruit Development in Teasle Gourd (Kakrol, Momordica dioica Roxb.)
}

\author{
Mohammad Golam RASUL ${ }^{1 *}$, Mohammad Abdul Khaleque MIAN ${ }^{1}$, \\ Yasuhiro $\mathrm{CHO}^{2}$, Yukio OZAKI ${ }^{3}$ and Hiroshi OKUBO
}

\author{
Laboratory of Horticultural Science, Division of Agricultural Botany, Department of Plant Resources, \\ Faculty of Agriculture, Kyushu University, Fukuoka 812-8581, Japan \\ (Received November 9, 2007 and accepted November 30, 2007)
}

\begin{abstract}
An experiment was conducted with a view to find out the possibility of inducing parthenocarpic fruit in teasle gourd (kakrol, Momodrica dioica Roxb.). The experiment was laid out at BSMRAU, Gazipur, Bangladesh during summer season of 2001 and 2002. Seven plant growth regulators (PGR's) viz. auxins (NAA: naphthaleneacetic acid and 2,4-D: 2,4-dichlorophenoxyacetic acid), cytokinins (CPPU: N-(2-chloro-4 pyridyl)-N' phenyl urea, Fulmet: forchlorophenuron), gibberellin ( $\mathrm{GA}_{3}$ : gibberellin $\mathrm{A}_{3}$ ) and auxin transport inhibitors (TIBA: 2, 3, 5-triiodobenzoic acid and MH: maleic hydrazide) with three concentrations $(25,50$ and $100 \mathrm{ppm}$ ) were sprayed at three times (a day before, at and a day after anthesis) with split-split plot design. Out of seven, only three PGR's (2,4-D, Fulmet and CPPU) were effective to parthenocarpic fruit development. Fruit size and weight increased with increase of concentration of PGR's except 2,4-D. Induced parthenocarpic fruits had no seeds. Control treatments (water spray) produced no fruits. The results revealed the possibility of developing parthenocarpy or seedless fruit using PGR's in teasle gourd.
\end{abstract}

\section{INTRODUCTION}

Teasle gourd (Momordica dioica Roxb) belongs to the genus Momordica in Cucurbitaceae. It is also known as kakrol or spine gourd. It shows dioecious, annual and viny habits, and propagated vegetatively through tuberous root. It is rich in carotene, protein, carbohydrate (Rashid, 1993) and vitamin C (154.7 mg/100 g of edible portion) (Bhuiya et al., 1977). Teasle gourd is one of the popular and delicious summer vegetables in Bangladesh with higher demand. It is two times more profitable than rice, wheat and any other summer vegetables (Das, 1988). Nowadays it is considered as an exportable vegetable for its longer keeping quality. Teasle gourd has a number of problems relating to its yield and fruit quality. Among the problems, presence of a large number of seeds in the fruits (decrease palatability) and regular cumbersome hand pollination (increase cost of production) are noticeable. Besides, early fruit development and seed formation restrict the development of additional fruits in cucumber (Denna, 1973; Tiedjens, 1928). This may be due to competition for metabolites by early developing fruit over later fruits or to the production of plant hormones by developing seeds, which inhibit further development (McCollum, 1934). Development of seedless fruit and unnecessary hand pollination can be

\footnotetext{
Department of Genetics and Plant Breeding, Bangabandhu Shiekh Mujibur Rahman Agricultural University, Salna, Gazipur 1706, Bangladesh

Laboratory of Horticultural Science, Division of Agricultural Botany, Department of Plant Resources, Graduate School of Bioresource and Bioenvironmental Sciences, Kyushu University, Fukuoka 812-8581, Japan

Laboratory of Agricultural Ecology, Division of Agricultural Ecology, Department of Plant Resources, Faculty of Agriculture, Kyushu University, Fukuoka 811-2307, Japan

* Corresponding author (E-mail: mdgolam@yahoo.com)
}

achieved by genetically (natural parthenocarpy) or by chemically induced parthenocarpy.

There are many methods available to produce parthenocarpic fruits in many crops. They are the uses of synthetic growth promoting factors (Lipari and Paratore, 1988), transport inhibitors of growth promoting factors (Robinson et al., 1971, Cantliffe, 1977), mutants capable of parthenocarpic development (Lin et al., 1988), pollination with incompatible pollen (Taso, 1980), X-ray irradiated mentor pollen (Morishita and Sugiyama, 1997; Sugiyama and Morishita, 2002) or plants altered in their ploidy level (Kihara, 1951).

In absence of natural or genetic parthenocarpy, alternate method should be adopted to have seedless fruit. Parthenocarpy can be induced in many crops (cucumber, tomato, bottle gourd, brinjal, Cucurbita, watermelon, etc.) by applying exogenous auxins (Homan, 1964; Elassar et al., 1974; Takashima and Hatta, 1955; Miyazaki, 1965; Terada and Masuda, 1941), gibberellins and cytokinins (Choudhury and Phatak, 1959; Elassar et al., 1974; Kulkarni and Rameshwar, 1978; Yu, 1999; Hayata et al., 2000) and also auxin transport inhibitors (Robinson et al., 1971; Cantliffe, 1977; Beyer and Quebedeaux, 1974).

Exogenous application of PGR's on parthenocarpic fruit development in teasle gourd has not yet been sufficiently investigated or reported. Considering the above facts, the present study was undertaken to examine the effects of exogenous PGR's (auxins and cytokinins) on the expression of parthenocarpy in teasle gourd.

\section{MATERIALS AND METHODS}

\section{Plant materials and cultivation}

The experiment was conducted at Bangabandhu Sheikh Mujibur Rahman Agricultural University 
(BSMRAU, former IPSA) research farm, Bangladesh, during March to September of 2001 and 2002. The tuberous roots of Rangpuri (Cl 3) genotype were used in this study. They were planted in earthen pots (containing a 1:1 mixture of soil and decomposed cowdung) on February 10, 2001 and February 8, 2002, respectively and watered. The tuberous roots began to sprout 20-25 days after potting. The sprouted tuberous roots were transplanted in pits $(30 \times 30 \times 30 \mathrm{~cm})$ in the experimental field on March 8, 2001 and March 10, 2002. The spacing between row to row and plant to plant was $2.0 \mathrm{~m}$ and $1.5 \mathrm{~m}$, respectively.

The plants were supported by bamboo sticks. When the plants were about $1 \mathrm{~m}$ high they were allowed to climb on rope net hanged vertically up to $2.5 \mathrm{~m}$ from the soil surface. Fertilization and other cultivation techniques (intercultural operations) were followed as recommended by Hussain and Rashid (1974).

\section{Experimental design and treatments}

The experiment was carried out in a split-split plot design with three replications. The treatments are as follows:

Time of application: A day before anthesis, at anthesis and a day after anthesis

Different PGR's: In 2001, auxins (NAA: naphthaleneacetic acid and 2,4-D: 2,4-dichlorophenoxyacetic acid), cytokinins (CPPU: N-(2-chloro-4 pyridyl)-N' phenyl urea and Fulmet: forchlorfenuron), gibberellin $\left(\mathrm{GA}_{3}\right.$ : gibberellin $\mathrm{A}_{3}$ ) and auxin transport inhibitors (TIBA: 2, 3, 5-triiodo benzoic acid and MH: maleic hydrazide) were tested. Each PGR of 50 ppm concentration was applied to ten ovaries at the time of anthesis and ovary length and diameter were recorded 5, 10 and 15 days after spray. Only three PGR's (2,4-D, Fulmet and CPPU) induced parthenocarpic fruit. In 2002, therefore, 2,4-D, Fulmet and CPPU were used.

Spraying concentrations: 25, 50 and $100 \mathrm{ppm}$. The concentrations in molar form for 2,4-D are respectively101, 202 and $404 \mu \mathrm{M}$ and for CPPU or Fulmet are 113, 226 and $452 \mu \mathrm{M}$, respectively.

Time of spraying was arranged in the main plot (main plots contain 27 plants per replication i.e. three plants/concentration/PGR in a replication, 3-5 first flashed flowers were sprayed in each plant), and different PGR's (9 plants/replication) and spraying concentrations ( 3 plants/replication) were applied to sub plot and sub-sub plot, respectively. The 2,4-D was dissolved in ethanol while CPPU was dissolved in 1\% DMSO (Dimethyl sulfoxide) to make stock solution. Ten to fifteen ovaries in three plants selected randomly at first fruiting stage were treated $(0.5 \mathrm{ml}$ per ovary) in each treatment with three replicates. All the treated flowers were bagged in the afternoon one day before anthesis, re-bagged after application and kept bagging up to 3-4 days to prevent from open pollination.

\section{Data collection and analysis}

Fruit set percent, length, diameter and weight of fruit were recorded 5, 10 and 15 days after spraying.
The mean data of 10-15 ovaries for each treatment were analyzed using standard statistical procedure of ANOVA and Duncan's Multiple Range Test (DMRT) to compare means of treatments and their interactions.

\section{RESULTS AND DISCUSSION}

2,4-D, Fulmet and CPPU induced parthenocarpic fruit (Table 1). The treated ovaries remained green and increased their size up to 15 days without developing seeds. While the ovaries treated with water (control), NAA, $\mathrm{GA}_{3}$, TIBA and $\mathrm{MH}$ turned yellow and dried up even 5 days after spaying.

The detailed experiment was conducted in 2002 with 2,4-D, Fulmet and CPPU.

Table 1. Response of different PGR's in parthenocarpic fruit development (2001)

\begin{tabular}{lccccc}
\hline & $\begin{array}{c}\text { Fruit set } \\
(\%)\end{array}$ & $\begin{array}{c}\text { Fruit } \\
\text { weight } \\
(\mathrm{g})\end{array}$ & $\begin{array}{c}\text { Fruit } \\
\text { length } \\
(\mathrm{mm})\end{array}$ & $\begin{array}{c}\text { Fruit } \\
\text { diameter } \\
(\mathrm{mm})\end{array}$ & Seed \\
\hline 2 4-D & 87.6 & 16.4 & 50.2 & 26.6 & Absent \\
Fulmet & 86.2 & 5.1 & 34.6 & 16.0 & Absent \\
CPPU & 73.1 & 6.2 & 32.2 & 16.6 & Absent \\
NAA & 0 & - & - & - & - \\
GA3 & 0 & - & - & - & - \\
TIBA & 0 & - & - & - & - \\
MH & 0 & - & - & - & - \\
Water (control) & 0 & - & - & - & - \\
\hline
\end{tabular}

\section{Effect of time of spraying on parthenocarpy}

The mean effect of time of spraying was statistically significant except on fruit length (Table 2). Fruit set was the highest (90.7\%) when the PGR's were sprayed at anthesis followed by the spraying a day after anthesis. It was evident that percent fruit set and subsequent fruit development was directly related to the amount of PGR's (particularly auxin) present in the ovary (Gustafson, 1939, Kim et al., 1992). It has been reported that parthenocarpic pat-2 tomato fruits showed slightly higher auxin (IAA) just before anthesis but more than 10 times higher IAA content at anthesis in comparison to control fruits (Mapelli et al., 1974).

Regarding fruit set, the treatments a day before anthesis and at anthesis were statistically similar. This indicated that the exogenous signal (PGR's, auxin analogues) triggered an increase in endogenous IAA and enhanced its activity in the ovary, which was responsible for promoting the highest fruit set and development at anthesis. This interpretation was consistent with that of Gustafson (1939) and Kim et al. (1992).

\section{Effect of PGR's on parthenocarpy}

Besides auxins (indole-3-acetic acid and its analogues), exogenous cytokinins have also been used to induce parthenocarpic fruit development in many crops (Schwabe and Mills, 1981). The maximum fruit set was obtained with 2,4-D (91.8\%) followed by Fulmet (90.2\%), which was statistically similar but it was dif- 
Table 2. Mean effect of time of application, PGR's and their concentrations on parthenocarpic fruit development (2002)

\begin{tabular}{|c|c|c|c|c|c|}
\hline Treatment & Fruit set (\%) & $\begin{array}{l}\text { Fruit weight } \\
\text { (g) }\end{array}$ & $\begin{array}{l}\text { Fruit length } \\
\text { (mm) }\end{array}$ & $\begin{array}{l}\text { Fruit diameter } \\
\text { (mm) }\end{array}$ & Seed \\
\hline One day before anthesis & $88.3 \mathrm{ab}$ & $7.2 \mathrm{~b}$ & 37.5 & $18.2 \mathrm{~b}$ & Absent \\
\hline At anthesis & $90.7 \mathrm{a}$ & $10.7 \mathrm{a}$ & 42.2 & $20.9 \mathrm{a}$ & Absent \\
\hline One day after anthesis & $79.1 \mathrm{~b}$ & $9.8 \mathrm{a}$ & 39.8 & $20.6 \mathrm{a}$ & Absent \\
\hline F test & $*$ & $* *$ & NS & $*$ & \\
\hline $2,4-\mathrm{D}$ & $91.8 \mathrm{a}$ & $16.5 \mathrm{a}$ & $51.2 \mathrm{a}$ & $26.7 \mathrm{a}$ & Absent \\
\hline Fulmet & $90.2 \mathrm{a}$ & $5.0 \mathrm{~b}$ & $35.5 \mathrm{~b}$ & $16.2 \mathrm{~b}$ & Absent \\
\hline CPPU & $76.1 \mathrm{~b}$ & $6.1 \mathrm{~b}$ & $32.7 \mathrm{~b}$ & $16.7 \mathrm{~b}$ & Absent \\
\hline F test & $* *$ & $* *$ & $* *$ & $* *$ & \\
\hline 25ppm & $80.2 \mathrm{~b}$ & $7.7 \mathrm{c}$ & $33.8 \mathrm{c}$ & $17.5 \mathrm{c}$ & Absent \\
\hline $50 \mathrm{ppm}$ & $88.9 \mathrm{a}$ & $8.7 \mathrm{~b}$ & $40.3 \mathrm{~b}$ & $20.0 \mathrm{~b}$ & Absent \\
\hline $100 \mathrm{ppm}$ & $89.1 \mathrm{a}$ & $11.3 \mathrm{a}$ & $45.4 \mathrm{a}$ & $22.1 \mathrm{a}$ & Absent \\
\hline F test & $* *$ & $* *$ & $* *$ & $* *$ & \\
\hline Mean & 86.1 & 9.2 & 39.8 & 19.9 & \\
\hline
\end{tabular}

ferent from CPPU (76.1\%) (Table 2). In teasle gourd, higher percent (88.9\%) of fruit set was also observed by applying 2,4-D against NAA and IAA (Vijay and Jalikop, 1980). The larger fruit (16.5 g) was also obtained when the ovary was sprayed with $2,4-\mathrm{D}$. The size of fruit (fruit length and diameter) varied considerably under different PGR treatments. For fruit length, the result showed that 2,4-D produced longer fruits as compared to Fulmet and CPPU. The 2,4-D enhanced the fruit growth sharply up to 10 days after treatment and then slowly up to 15 days. But in case of Fulmet and CPPU initial growth was high until 5 days, which almost stopped at 10 days and not much further increment. The fruit diameter increased up to 10 days for all PGR's. Vijay and Jalikop (1980) observed higher fruit size by applying 2,4-D and 2,4,5-T than by NAA and IAA in teasle gourd.

The performance of cytokinin derivatives (Fulmet and CPPU) for different parameters was statistically similar except for fruit set percentage. CPPU and Fulmet are chemically similar, commonly called Forchlorofenuron, so their effect should be similar. The differences in their effect for fruit set percentage might be due to the adjuvant used, CPPU in DMSO and Fulmet in ethanol. Though CPPU is the cytokinin with strongest activity ever known (Takahashi et al., 1978) but in our study, the performance of Fulmet and CCPU was not much encouraging as compared to results reported in other crops (Chin et al., 1991; Lewis et al., 1996). CPPU induced more parthenocarpic fruits and also improved fruit set in Chinese white gourd (Lagenaria leucantha) than NAA, $\mathrm{GA}_{3}, \mathrm{BA}, \mathrm{DPU}$ and 4-PU (Yu, 1999).

Control treatment (water spray) did not produce fruits. It turned ovaries yellow after 5 days of the treatment and shrinked and then the ovaries dropped down quickly. So the data on water control were not incorpo- rated in the statistical analysis and also in the Table 2.

\section{Effect of concentrations of PGR's on parthenocarpy}

PGR's sprayed at 100 and 50 ppm showed similar results in percent fruit set, but fruit set was low at $25 \mathrm{ppm}$ (Table 2). The application of $100 \mathrm{ppm}$ PGR's produced the largest fruit $(11.3 \mathrm{~g})$ while $25 \mathrm{ppm}$ produced the smallest (7.7 g) fruit. Fruit size (length and diameter) and weights were increased with the increment of the concentrations of PGR's. Fruit size increased up to 10 days after spraying and beyond that it was almost stopped, which might be due to the limitation of assimilate supply and cell division by the PGR's for such long time. Vijay and Jalikop (1980) observed remarkable differences in fruit weight and fruit set with the application of different concentration of growth regulators in teasle gourd. It is likely that fruit size is an important factor to be considered in the determination of hormonal concentration for parthenocarpic development of fruits.

Elassar et al. (1974) reported that synthetic auxin when applied directly to flower of muskmelon at anthesis caused parthenocarpic fruits. Watkins and Cantliffe (1980) reported that exogenously applied NAA enhanced fruit set in Cucumis sativus L. Application of NAA and IAA on the ovary accumulated auxin in it which triggered fruit set and subsequent growth of Cucumis sativus (Kim et al., 1992).

The similar experiments were conducted in Kyushu University in 2000 and 2001 with different strains. The results were quite similar to those described above. Parthenocarpic fruit is obtainable by chemical treatment, although the fruit quality is not yet satisfactory.

\section{CONCLUSION}

In the present findings, 2,4-D showed better effect 
on growth and fruit set in teasle gourd than Fulmet and CPPU (cytokinins). Fruit size and weight were mostly increased with increase of concentration of PGR's. The results revealed that PGR's showed the possibility of developing parthenocary or seedless fruit in teasle gourd.

\section{ACKNOWLEDGMENTS}

We acknowledge Japan Society for the Promotion of Sciences (JSPS) for granting scholarship for the first author during study.

\section{REFERENCES}

Beyer, E. M., B. Quebedeaux 1974 Parthenocarpy in cucumber: mechanism of action of transport inhibitors. J. Amer. Soc. Hort. Sci., 99: 385-390

Bhuiya, M. R. H., A. K. M. A. Habib and M. M. Rashid 1977 Content and loss of vitamin $\mathrm{C}$ in vegetables during storage and cooking. Bangladesh Hort., 9: 1-4

Cantliffe, D. J. 1977 The induction of fruit set in cucumber by chloroflurenol with or without pollination. HortScience, $\mathbf{7}$ : 474-476

Chin, R., Y. Hayata, Y. Niimi and R. Isoda 1991 Effect of tomatotone or fulmet treatment on growth and quality of tomato fruit. J. Japan. Soc. Hort. Sci., 60 (Suppl. 1): 276-277 (in Japanese)

Choudhury, B. and S. C. Pathak 1959 Sex expression and fruit development in cucumber (Cucumis sativus $\mathrm{L}$ ) as affected by gibberellin. Indian J. Hort., 16: 233-235

Cruiz-Castillo, G., D. J. Woolley and G. S. Lawes 2002 Kiwifruit size and CPPU response are influenced by the time of anthesis. Scientia Hortic., 95: 23-30

Das, B. C. 1988 Teasle Gourd Chash 1st Edition. Sima Devi, Mala Kuthir, Bagan Bari, Bhrammanbaria, Bangladesh, pp. 40-43 (in Bengali)

Denna, D. W. 1973 Effect of genetic parthenocarpy and gynoecious flowering habit on fruit production and growth of Cucumis sativus L. J. Amer. Soc. Hort. Sci., 98: 602-604

Elassar, G., J. Rudich, D. Palevitch and N. Kedar 1974 Induction of parthenocarpic fruit development in cucumber by growth regulators. HortScience, 9: 238-239

Gillapsy, G., H. Ben-David and W. Grulssem 1993 Fruits: a development perspective. Plant Cell. 5: 1439-1451

Gustafson, F. G. 1939 The cause of natural parthenocarpy. Amer. J. Bot., 26: 135-138

Hayata, Y., X. Li and Y. Osajima 2000 CPPU (retreatment), 4-CPA and NAA improve the growth and quality of parthenocarpic melon fruit induced by CPPU. Environ. Cont. Biol., 38: $129-134$

Homan, D. 1964 Auxin transport in physiology of fruit development. Plant Physiol., 39: 982-986

Hussain, M. A. and M. M. Rashid 1974. Floral biology of teasle gourd. Bangladesh Hort., 2: 1-4

Kihara, H. 1951 Triploids watermelons. Proc. Amer. Soc. Hort. Sci., 58: $217-230$

Kim, I. S., H. Okubo and K. Fujieda 1992 Endogenous level of IAA in relation to parthenocarpy in cucumber (Cucumis sativus L). Scientia Hortic., 52: 1-8

Kulkarni, V. and A. Rameshwar 1978 Natural and gibberellic acid induced parthenocarpy in mango: cv. Thamva. Curr.
Sci., 47: 353-355

Lewis, D. H., G. K. Burge, M. E. Hopping and P. E. Jameson 1996 Cytokinin and fruit development in the kiwifruit (Actinidia deliciosa): Effect of reduced pollination and CPPU application. Physiol. Plant., 98: 187-195

Lin, S., W. L. George and W. E. Splittstoesser 1988 Expression and inheritance of parthenocarpy in 'Severianin' tomato. J. Hered., 75: 62-66

Lipari, V. and A. Paratore 1988 Parthenocarpy and auxinic treatments in fruiting of tomato in a cold greenhouse. Acta Hort., 229: 307-312

Mapelli, S., C. Frova, G. Torti and G. P. Soressi 1978 Relationship between set, development and activities of growth regulators in tomato fruits. Plant Cell Physiol., $\mathbf{1 9}$. 1281-1288

McCollum, J. P. 1934 Vegetative and reproductive responses associated with fruit development in cucumber. Cornell Agr. Expt. Sta. Mem., 163: 1-27

Miyazaki, H. 1965 Study of parthenocarpy of watermelon. I. Effect of plant bioregulator on parthenocarpy of watermelon. Bull. Miyazaki Agr. Coll., 1: 3-8

Morishita. S. and K. Sugiyama 1997 Creation of seedless fruit. Pattent Appl. No JP19970279331; PN: JP11103705

Rashid, M. M. 1993 Shabji Bijgan, 2nd edition. Rashid Publishing House, Banani, Dhaka (in Bengali)

Robinson, R. W., D. J. Cantliffe and S. Shannon 1971 Morphactin-induced parthenocarpy in the cucumber. Science, 171: 1251-1252

Schwabe, W. W. and J. J. Mills 1981 Hormones and parthenocarpic fruit set: A literature survey. Hortic. Abstr. 51: 661698

Shishido, Y., Y. Hori and S. Shikano 1990 Effect of benzyladenine on translocation and distribution of photoassimilates during fruit setting and development in cucumber plant. $J$. Japan. Soc. Hort. Sci., 59: 129-135

Sugiyama, K. and M. Morishita 2002 New method of producing diploid seedless watermelon fruits. Japan. Agri. Res. Quart. (JARQ), 36: 177-182

Takahashi, S., K. Shudo, T. Okamoto, K. Yamada and Y. Isogai 1978 Cytokinin activity of N-phenyl-N'-(4-pyridyl) urea derivatives. Phytochem., 17: 1201-1206

Takashima, S. and S. Hatta 1955 Effect of phytoplant bioregulators on parthenocarpy in cucurbits. J. Hort. Assn. Japan, 24: $59-61$

Taso, T. 1980 Growth substances: role in fertilization and sex expression. In "Plant Growth Substances", ed. by F. Skoog, Spring-Verlag. New York, pp. 345-348

Terada, T. and K. Masuda 1941 Parthenocarpy in watermelon by single or complex application of plant bioregulators. Agr. Hort., 15: 458-468

Tiedjens, V. A. 1928 Sex ratio in cucumber flowers as affected by different conditions of soil and light. J. Agric. Res., $\mathbf{3 6}$ : $721-746$

Vijay, O. P. and S. H. Jalikop 1980 Production of parthenocarpic fruit growth regulators in teasle gourd (Momordica cochinchinensis Spreng). Indian J. Hortic., 37: 167-169

Watkins, J. T. and D. J. Cantliffe 1980 Regulation of fruit set in Cucumis sativus by auxin and auxin transport inhibitor. J. Amer. Soc. Hort. Sci., 105: 603-607

Wood, J. W. and T. D. Fontaine 1952 Synthetic plant growth regulators. III. 2,4-dichloro-phenoxyacetyl derivatives of amino acids. J. Org. Chem., 17: 891-896

Yu, J. Q. 1999 Parthenocarpy induced by N-(2-chloro-4pyridyl)-N`-phenylurea (CPPU) pevents flower abortion in Chinese white-flowered gourd (Lagenaria leucantha). Env. Exp. Bot., 42: 121-128 